\title{
A Comparative Study on the Reproductive Success of Two Species of Sesamum L. (Pedaliaceae)
}

\author{
Jeyaraj S*, S Suhara Beevy \\ Department of Botany, University of Kerala, Kariavattom, India \\ Received February 9, 2020; Revised March 2, 2020; Accepted March 12, 2020
}

Copyright $\bigcirc 2020$ by authors, all rights reserved. Authors agree that this article remains permanently open access under the terms of the Creative Commons Attribution License 4.0 International License

\begin{abstract}
A comprehensive knowledge on reproductive traits of a species is a prerequisite in utilizing the existing germplasm efficiently for crop improvement and to develop superior plants for grower acceptance and market profitability. Studies on floral biology and reproductive behaviour of the wild and cultivated species of Sesamum viz, S. radiatum and S. indicum from Kerala were carried out in the present investigation. Analysis of floral morphology revealed flowers were bisexual, zygomorphic and hypogynous with characteristic pink coloured flowers in $S$. radiatum and white in $S$. indicum. The study on phenoevents of the species showed earlier blooming and anther dehiscence in S. indicum compared to $S$. radiatum. Pollen fertility was found to be high in both species. Field observations on floral visitors showed that the flowers were regularly foraged by various insects such as ants, bees and beetles, of these the most frequent one was a species of Xylocopa. Hybridization studies revealed high percentage of crossability in the cross $S$. radiatum x $S$. indicum, while the reciprocal cross failed to set fruit, that may be due to the reproductive barriers existing between the species.
\end{abstract}

Keywords Breeding System, Phenology, Pollen Viability, Pollinators, S. radiatum, S. indicum

\section{Introduction}

The genus Sesamum belonging to the family Pedaliaceae comprised of 14 genera [21]. The family is distinguished by annual or perennial herbs, rarely shrubs or small trees with mucilage glands. According to Kobayashi the genus Sesamum consist of 36 species, and is distributed in the tropical, southern Africa and in south and southeast Asia [15]. Its representation is confined to six species in Kerala, of these sesame (S. indicum) is the only cultivated species popularly known as Queen of oil seeds. It was the first crop processed for oil as well as one of the earliest condiments [7]. Sesame is very efficient in lowering cholesterol level and also protect liver from oxidative damages [1].

The species $S$. radiatum is wild relative of sesame commonly known as benniseed, black benniseed, black sesame and vegetable sesame. The leaves, seeds, and oil of this wild species serves as food especially in rural areas of many African countries including Benin [10]. The seeds are eaten whole or as a paste. The leaves are also used medicinally as a laxative, and an antidote to scorpion venom, and to treat sprains and ease child birth [14]. It is also considered as a potential source of many valuable traits [17]. According to FAOSTAT, India is one of the major producers of sesame worldwide. Though it lags behind other major oil seed crops as concerns genetic improvement. Hence it is crucial to enhance sesame germplasms for higher productivity and seed quality to efficiently cope up with growing demand of its oil. Though the wild species are the potential source of many valuable genes, transfer of these genes in to cultivated sesame has not been successful. Earlier attempts to introgress useful genes from wild relatives into sesame have been less successful due to low crossability [19], [20].

Studies on reproductive biology is important for determining barriers to fruit and seed set and to understand pollination and breeding system that regulate the genetic structure of a population [23]. However, studies on floral biology and reproductive behaviour of Sesamum species were meagre. Hence the present investigation was undertaken with a view to understand the different aspects related to the reproductive biology of wild and cultivated species of Sesamum.

\section{Materials and Methods}

\subsection{Study System}

The study was undertaken in two species of Sesamum 
viz, the cultivated $S$. indicum (Fig. 1b) and the wild $S$. radiatum (Fig. 1a) grown in the botanical garden, Department of Botany, University of Kerala, Thiruvananthapuram during the year 2015.

\subsection{Phenology}

To study phenology of the species, the onset of major events of vegetative and reproductive growth that occurred during the year was considered. The observations were made on every day during the flowering period. The reproductive period was calculated from the day of emergence of the flower bud till fruit maturity. Date of initiation of flowering, optimum flowering, end of flowering, and fruiting period were also recorded.

\subsection{Morphology}

Both the vegetative and reproductive morphological characters were considered for the investigation. Under the vegetative characters, morphology of stem, leaf, and roots were studied, while the characters such as average number of flowers born on a plant, number of open flowers, flower longevity, floral morphology, anther dehiscence, fruit maturation, and fruit dispersal were analyzed in floral biology. The dimensions of floral parts were measured by a Vernier Caliper (Digital Caliper, 0-200 mm) and the morphological studies were carried out with the help of a Stereo microscope (Olympus SZ61). Fruit maturation and fruit dispersal were recorded once in a week, while anther dehiscence was recorded at a regular interval of 30 minutes.

\subsection{Pollen Biology}

\subsubsection{Pollen-Ovule Ratio}

Estimation of pollen production in anthers was studied according to Shivanna and Rangaswamy [22]. Ten randomly selected flower buds just before anthesis were used to find out pollen ovule ratio. Undehisced anthers were suspended on a known volume $(1 \mathrm{ml})$ of sucrose solution in a $5-10 \mathrm{ml}$ vial and were crushed with a needle to release all the pollen grains from the anther. Then the suspension was repeatedly mixed, while mixing, a suitable volume of this suspension $(20 \mu \mathrm{l})$ was taken on a clean slide and the number of pollen grains was counted manually using image analyzer (Leica Model DM 2000) at X20 magnification. Then the total number of pollen grains in the suspension was calculated by using the following formula:

(Total volume of pollen suspension x No.of pollen grains in the sampled suspension)/(Volume of suspension used for counting)

The average number of pollen grains per anther was calculated and multiplied with the number of anthers per flower to know the average number of pollen grains produced per flower. Ten randomly selected floral buds were taken to count the average number of ovules per ovary, and each ovule was removed from the placenta and suspended in a drop of water to count at X40 magnification under dissecting microscope. Pollen - ovule ratio was calculated following Cruden's method [9].

\subsubsection{Pollen Histochemistry}

Histochemical analysis of the pollen grains was carried out to know the distribution of primary metabolites such as starch, proteins, and lipids. For this, freshly dehisced pollen grains were collected and analyzed with respective chemicals.

\subsubsection{Pollen Fertility and Viability}

Pollen grains collected from the plants at the time of anthesis were crushed in acetocarmine-glycerine mixer $(1: 1)$ on a clean glass slide. Stainability of pollen grains was observed through the microscope and the percentage of sterility was calculated. Flourochromatic (FCR) test was used to assess the pollen viability following the method of Heslop- Harrison and Heslop- Harrison [12].

\subsubsection{Pollen Germination}

Both in-vitro and in-vivo germination studies were carried out. Brewbaker's medium was used to check in-vitro germination of the pollen grains [4]. In-vivo pollen germination on the stigmatic and stylar tissue was verified by staining with cotton blue. Stained pistils were placed on clean glass slides and added a drop of glycerine. Mounted pistils were observed under image analyzer (Leica Model DM 2000) and photomicrographs were taken.

\subsection{Stigma Receptivity}

Stigmatic peroxidase activity method was adopted to evaluate the stigma receptivity [13]. Intact styles of emasculated flowers were placed on a glass slide contains a drop of $3 \%$ hydrogen peroxidise. Stigmas that produced bubbles within 2-3 min were considered as receptive.

\subsection{Breeding System}

Pollination experiments were carried out to analyze the breeding system and the rate of fruit and seed set

\subsection{Pollination Biology}

The type of floral visitors and their foraging behaviour were carefully observed during the entire flowering period at regular intervals throughout the day. Insects visiting the flowers were anaesthetized and identified with the help of an entomologist, Department of Zoology, University of Kerala. Number of insects visiting the flowers was recorded. The number of visits made and the average time 
spent by an insect on the flower was also recorded.

\subsection{Seed Germination}

Seed germination of both the species was checked by soaked cotton method and seed viability was analyzed by using Tetrazolium salts [8].

\subsection{Statistical Analysis}

All the quantitative data were subjected to the analysis of variance (ANOVA) using SPSS Statistics (SPSS Inc. Chicago, IL, USA).

\section{Results}

\subsection{Phenology}

Phenological study of the species, S. indicum and $S$. radiatum showed not much variation in the pattern of fruiting and senescence but they showed variations in the life cycle duration and growing period (S. indicum - March - October, S. radiatum - February - December). It was found that the peak flowering period of $S$. indicum was from June - October, whereas in S. radiatum it was from May - November. Negligible differences were noticed in the occurrence of senescence in both, that is declining of flowering begun in the first week of November followed by leaf shedding and that continued up to December. At the end of December, the plants were completely devoid of leaves with the fully matured fruits. No significant differences were observed in the number of flowers opening per day. Difference was observed between the wild and cultivated species in the number of nodes to first flower. In S. radiatum the first flower was born on the $12^{\text {th }}$ or $13^{\text {th }}$ node, but in the cultivated species it was on the $8^{\text {th }}$ or $9^{\text {th }}$ node.

\subsection{Morphology}

Stem often contained purple dots with white hispid hairs in S. radiatum, while in S. indicum it was glabrous in nature without any colouration. In both the taxa the leaves were petiolate, simple and alternate but at the tip it was sub-opposite with reticulate, convergent venation. The leaves of wild taxon were hairy with purple dots as in the stem, while it was absent in the cultivated taxon. Basal leaves were comparatively larger, ovate having long petioles of $1.5-4.2 \mathrm{~cm}$ long with dentate margin in both. There were no remarkable differences observed in the stem shape and root system.

\subsection{Floral Biology}

Solitary axillary, bisexual, zygomorphic, hypogynous and shortly pedicellate flowers were produced in acropetal succession in both the species. However, the species differed in colour of the flower, S. radiatum was characterized by pink flowers (Fig. 1c), whereas in $S$. indicum it was white (Fig. 1d). Flowers were densely pubescent and the hairs were covered on outer side of the corolla tube. Corolla of $S$. radiatum was highly pigmented, while that of $S$. indicum it was slightly pigmented. Two extrafloral nectary glands present at the base of the leaf were yellow in colour in $S$. indicum (Fig. 1t) while purple in S. radiatum (Fig. 1s).

Anthesis occurred $30 \pm 2$ days after the initiation of floral buds. The two species showed variation in the time of anthesis i.e., $06.00 \mathrm{hr}-07.00 \mathrm{hr}$ in $S$. indicum and $06.00 \mathrm{hr}-$ $07.30 \mathrm{hr}$ in $S$. radiatum (Table 1). Anthesis and anther dehiscence occurred simultaneously in the cultivated taxon. Anther dehiscence was found to be a few hours after anthesis in S. radiatum (Table 1). After anthesis, the bifid stigma began to separate and become receptive. The release of pollen grains started by the two stamens located at the upper part of the stigma, followed by the remaining two which is located below the stigma. Majority of the pollen grains were contributed by the two large stamens. 

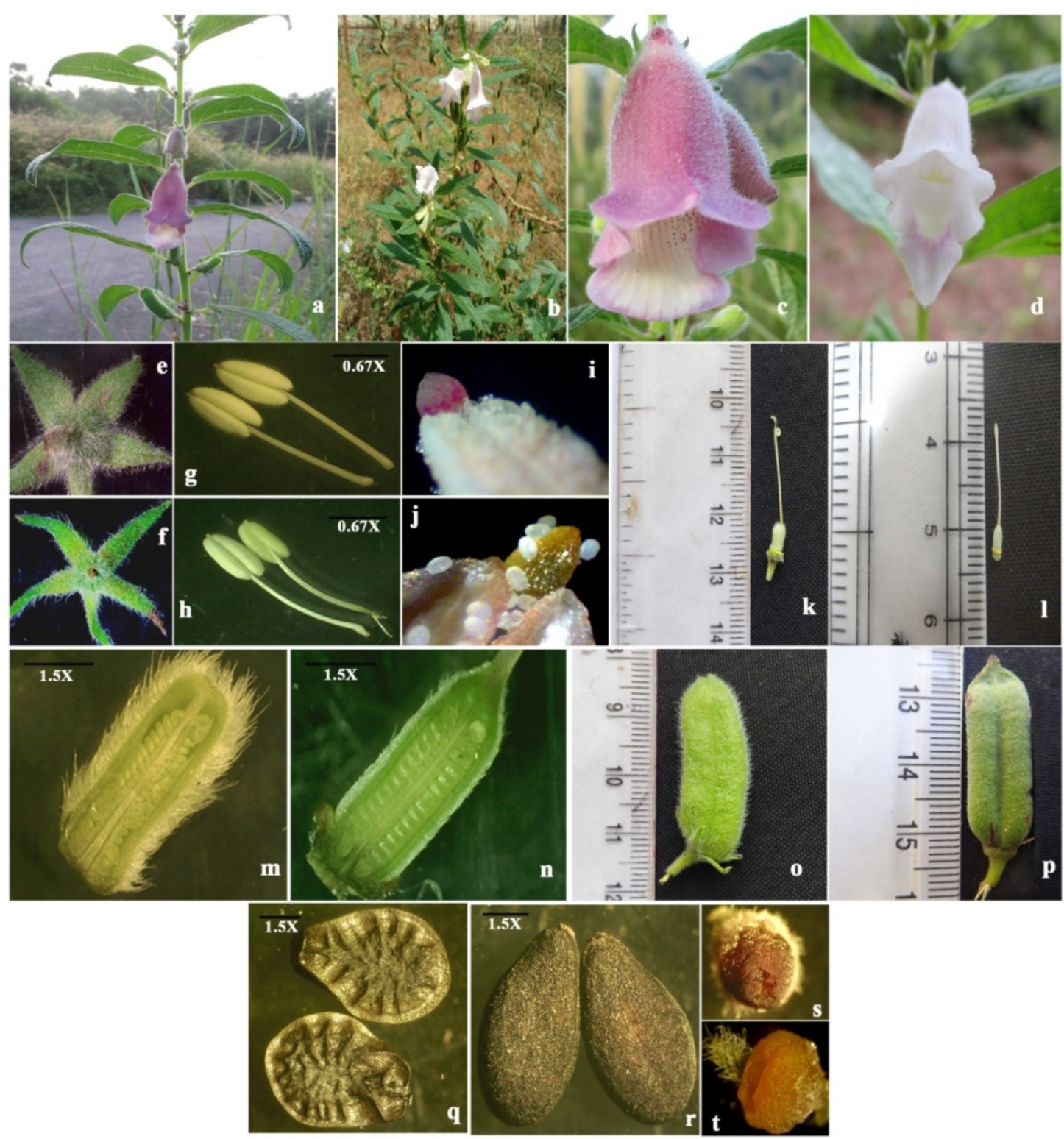

Figure 1 a-t. Floral morphology of Sesamum radiatum and S. indicum. a and b Flowering twig of S. radiatum and S. indicum. c and d Single flower of S. radiatum and S. indicum. e and $\mathbf{f}$ Calyx of S. radiatum and S. indicum. $\mathbf{g}$ and $\mathbf{h}$ Stamens of S. radiatum and S. indicum. $\mathbf{i}$ and $\mathbf{j}$ Staminal tip of S. radiatum and S. indicum. $\mathbf{k}$ and $\mathbf{l}$ Gynoecium of $S$. radiatum and S. indicum. $\mathbf{m}$ and $\mathbf{n}$ L.S of ovary of S. radiatum and S. indicum. $\mathbf{o}$ and $\mathbf{p}$ Capsules of $S$. radiatum and $S$. indicum. $\mathbf{q}$ and $\mathbf{r}$ Seeds of $S$. radiatum and $S$. indicum. $\mathbf{s}$ and $\mathbf{t}$ Extrafloral nectary gland of $S$. radiatum and $S$. indicum 
Table 1. Floral Biology of Sesamum species

\begin{tabular}{|c|c|c|c|}
\hline Sl. No & Parameters & S. radiatum & S. indicum \\
\hline 1 & Habit & Erect & Erect \\
\hline 2 & Inflorescence type & Solitary & Solitary \\
\hline 3 & Flower description & $\begin{array}{l}\text { Bisexual, regular } \\
\text { gamopetalous }\end{array}$ & $\begin{array}{l}\text { Bisexual, regular } \\
\text { gamopetalous }\end{array}$ \\
\hline 4 & Sepal hairiness & Strong or profuse & Weak or sparse \\
\hline 5 & Corolla shape & Funnel shaped & Funnel shaped \\
\hline 6 & Corolla hairiness & Strong or profuse & Medium \\
\hline 7 & Exterior corolla colour & Pink & White \\
\hline 8 & Interior corolla colour & Pinkish white & Whitish pink \\
\hline 9 & Corolla interior pigmentation & Purple dots & A few purple dots \\
\hline 10 & Flower angle to main stem & Drooping $\left(>90^{\circ}\right)$ & Drooping $\left(>90^{\circ}\right)$ \\
\hline 11 & Floral symmetry & Zygomorphic & Zygomorphic \\
\hline 12 & Stamen type & Dydinamous, epipetalous, & Dydinamous, epipetalous, \\
\hline 13 & Anther hairiness & Hairy & weak \\
\hline 14 & Anther tip colour & Pink & Yellow \\
\hline 15 & $\begin{array}{l}\text { Attachment of filament to } \\
\text { anther }\end{array}$ & Dorsifixed & Dorsifixed \\
\hline 16 & Style & $\begin{array}{l}\text { stigma position at anthers } \\
\text { level }\end{array}$ & $\begin{array}{l}\text { stigma position at anthers } \\
\text { level }\end{array}$ \\
\hline 17 & Position of ovary & Hypogynous & Hypogynous \\
\hline 18 & Fruit type & Capsular & Capsular \\
\hline 19 & Fruit shape & Narrow oblong & Broad oblong \\
\hline 20 & Fruit hairiness & Strong or profuse & Weak or sparse \\
\hline 21 & $\begin{array}{l}\text { Anthocyanin coloration of } \\
\text { capsule }\end{array}$ & Present & Absent \\
\hline 22 & Fruit dehiscence & Longitudinal & Longitudinal \\
\hline 23 & Fruit colour & Greenish pink & Green \\
\hline 24 & Number of locules per capsule & Four & Four \\
\hline 25 & Seed coat texture & Rough & Smooth \\
\hline 26 & Seed coat colour & Light brown & Bright black \\
\hline 27 & Seed shape & Oval with convex side & Elongated \\
\hline 28 & Extrafloral nectar gland colour & Pink in colour & Yellow in colour \\
\hline
\end{tabular}

\subsection{Pollen Biology}

\subsubsection{Pollen/Ovule Ratio}

The average number of pollen grains produced per small anther in the wild and cultivated taxa of Sesamum were $8066.66 \pm 402.73$ and $3758.33 \pm 272.70$ respectively, while in the larger stamen it was $9126.67 \pm 339.73$ (S. radiatum) and $4583.32 \pm 542.77$ (S. indicum). The total number of pollen grains per flower was found to be $34386.67 \pm 856.85$ in $S$. radiatum, while it was $16683.32 \pm 1469.79$ in $S$. indicum. The average number of ovules per flower was calculated to be $89.00 \pm 3.05$ in S. radiatum and $46.60 \pm$ 3.20 in S. indicum. The pollen- ovule ratio was comparatively high in the wild species (389.53 \pm 13.89$)$ than the cultivated one $(366.02 \pm 32.57)$. According to Cruden (1977) the pollen- ovule ratio between 31.9- 396.0 are facultative autogamous (Table 1 ).

\subsubsection{Pollen Histochemistry}

Starch and protein deposition were found to be high in the pollen grains of both the species but the presence of lipid in both was less compared to starch and protein.

\subsubsection{Pollen Sterility}

It was observed that the pollen sterility was relatively high in S. radiatum (5.2- 6.1\%) (Fig. 2a) as compared to $S$. indicum (3.1- 3.7\%) (Fig.2b). Percentage of fertility was high in both species.

\subsubsection{Pollen Viability}

FCR test showed that $86 \%$ of the pollen grains were viable in the cultivated species, while in the wild it was $84 \%$ (Fig. 2c, d). Pollen germination was started 3- 4 hrs after anthesis. Most of the pollen grains of the two species were viable, while a few failed to germinate in in-vitro 
experiments. The percentage of pollen viability was $82 \%$ in $S$. indicum and $83 \%$ in S. radiatum. In open pollinated flowers (in-vivo) the number of pollen grains deposited and germinated on the stigmatic surface was high in S. indicum, but in $S$. radiatum it was less (Fig. 2e, f).

\subsection{Stigma Receptivity}

Stigmatic receptivity was examined using $\mathrm{H}_{2} \mathrm{O}_{2}$ (stigmatic peroxidase activity test) and it was found that stigmas at the time of anthesis produced more oxygen bubbles. Thus, indicates that stigmas were more receptive at the time of anthesis.

\subsection{Breeding System}

The cross-pollination experiments revealed cent percentage crossability in the cross between $S$. radiatum and S. indicum and only 36 - 39 seeds were observed, while in the reciprocal cross they failed to develop fruit and seeds (Table 2).

\subsection{Pollination Biology}

The flowers of both the cultivated and wild species were often visited by various insects such as bees, beetles, ants, and some spiders (Table 3). The most frequent one was a species of Xylocopa (Fig. 2j) and a few of them are occasional (Fig. 2g, i). Freshly opened flowers were attracted by the insects and they made their visit during day time especially between $09.00 \mathrm{am}-12.00 \mathrm{pm}$. Most of the insects spent about 3- $6 \mathrm{sec}$, and a few spent more than 20 sec while Xylocopa sp. spent about 6- 8 seconds per flower.
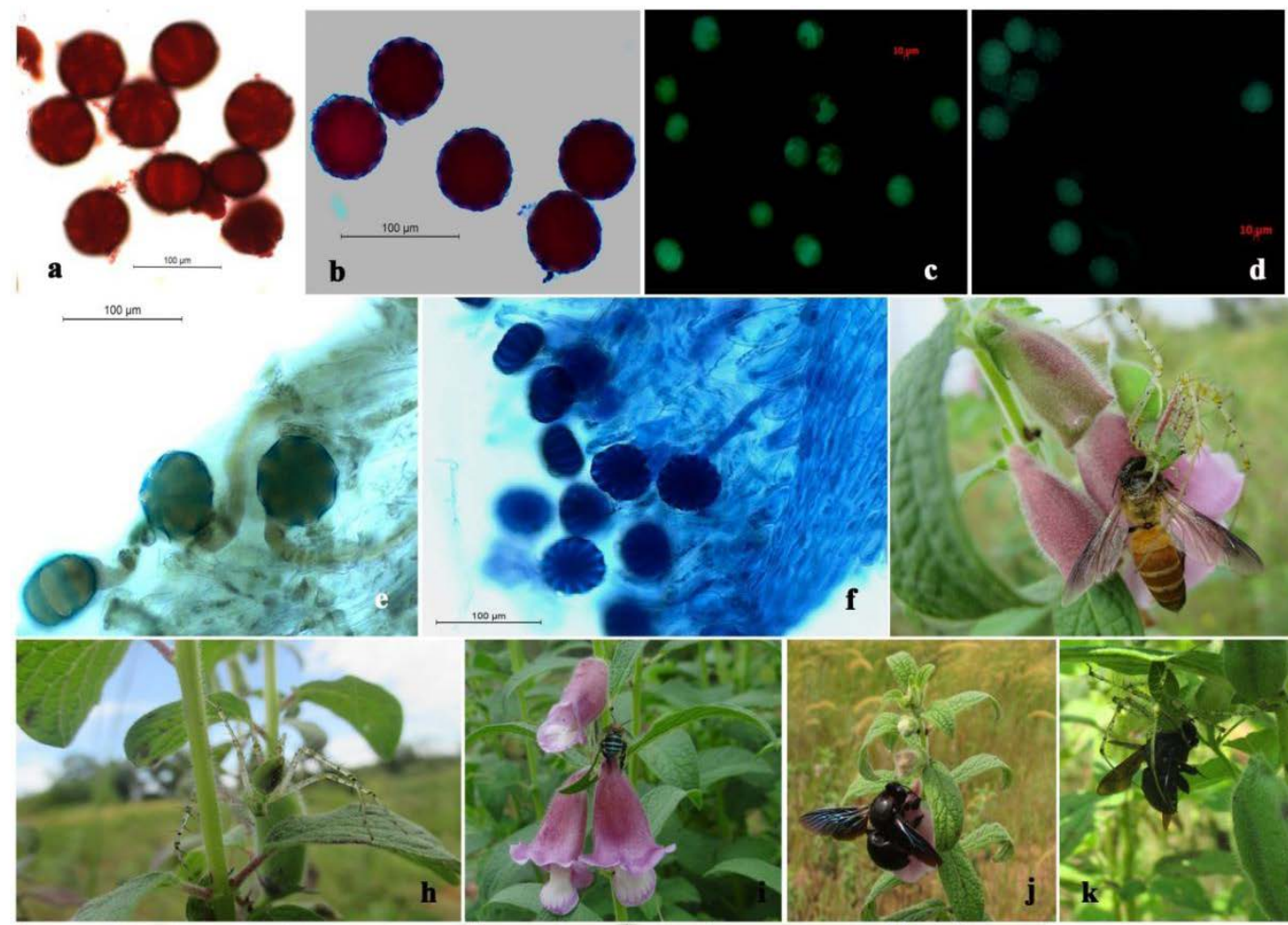

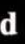

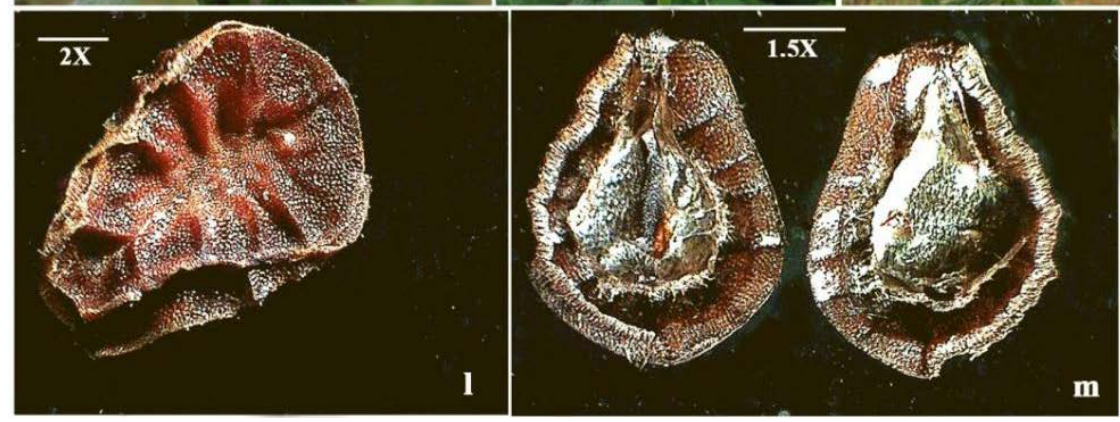

Figure 2 a-m. Reproductive characters of Sesamum radiatum and S. indicum. a and b Acetocarmine stained fertile pollen grains of $S$. radiatum and S. indicum. c and $\mathbf{d}$ fluorescence micrograph of fluorescein diacetate (FDA) stained pollen grains of $S$. radiatum and S. indicum. e and $\mathbf{f}$ Cotton blue stained stigmatic surface showing pollen germination of $S$. radiatum and $S$. indicum. g Green lynx spider capturing bee pollinator. h Green lynx spider. i Species of Amegilla (blue banded bee) sucking the nectar on S. radiatum. j Species of Xylocopa sucking the nectar on S. radiatum. k Green lynx spider capturing Xylocopa species. I Seed obtained from the cross between S. radiatum and S. indicum. m L. S of aborted seed obtained from the cross 
between S. radiatum and S. indicum

Table 2. Quantitative characters of S. radiatum and S. indicum

\begin{tabular}{|c|c|c|c|c|c|}
\hline Sl. No & \multicolumn{2}{|c|}{ Parameters } & $\begin{array}{l}\text { S. radiatum } \\
\text { (mean } \pm \mathrm{SE})\end{array}$ & $\begin{array}{l}\begin{array}{l}\text { S. indicum } \\
\text { (mean } \pm S E)\end{array} \\
\end{array}$ & F value \\
\hline 1. & \multicolumn{2}{|c|}{ Corolla length $(\mathrm{cm})$} & $3.57 \pm 0.10$ & $2.83 \pm 0.06$ & $37.853^{* * *}$ \\
\hline 2. & \multicolumn{2}{|c|}{ Corolla width (cm) } & $1.29 \pm 0.06$ & $0.72 \pm 0.02$ & $65.710^{* * *}$ \\
\hline \multirow{2}{*}{3.} & \multirow{2}{*}{$\begin{array}{l}\text { Length of } \\
\text { stamen }\end{array}$} & Large $(\mathrm{cm})$ & $1.65 \pm 0.03$ & $1.20 \pm 0.02$ & $110.455^{* * *}$ \\
\hline & & Small (cm) & $1.24 \pm 0.02$ & $0.96 \pm 0.01$ & $80.182^{* * *}$ \\
\hline 4. & \multicolumn{2}{|c|}{ Style length $(\mathrm{cm})$} & $1.95 \pm 0.04$ & $1.30 \pm 0.03$ & $143.491^{* * *}$ \\
\hline 5. & \multicolumn{2}{|c|}{$\begin{array}{l}\text { Distance between style and } \\
\text { short stamen }(\mathrm{cm})\end{array}$} & $0.71 \pm 0.04$ & $0.34 \pm 0.02$ & $48.700^{* * *}$ \\
\hline 6. & \multicolumn{2}{|c|}{$\begin{array}{l}\text { Distance between style and } \\
\text { large stamen }(\mathrm{cm})\end{array}$} & $0.30 \pm 0.06$ & $0.10 \pm 0.03$ & $7.200^{* *}$ \\
\hline 7. & \multicolumn{2}{|c|}{$\begin{array}{l}\text { No. of pollen grains per small } \\
\text { anther }\end{array}$} & $8066.66 \pm 402.73$ & $3758.33 \pm 272.70$ & $78.464^{* * *}$ \\
\hline 8. & \multicolumn{2}{|c|}{$\begin{array}{l}\text { No. of pollen grains per large } \\
\text { anther }\end{array}$} & $9126.67 \pm 339.73$ & $4583.32 \pm 542.77$ & $50.342^{* * *}$ \\
\hline 9. & \multicolumn{2}{|c|}{$\begin{array}{l}\text { No. of pollen grains per } \\
\text { flower }\end{array}$} & $\begin{array}{l}34386.67 \pm \\
856.85\end{array}$ & $16683.32 \pm 1469.79$ & $108.278^{* * *}$ \\
\hline 10. & \multicolumn{2}{|c|}{ No. of ovules per ovary } & $89.00 \pm 3.05$ & $46.60 \pm 3.20$ & $91.702^{* * *}$ \\
\hline 11. & \multicolumn{2}{|c|}{ Pollen- ovule ratio } & $389.53 \pm 13.89$ & $366.02 \pm 32.57$ & $0.441 \mathrm{NS}$ \\
\hline 12. & \multicolumn{2}{|c|}{ Fruit length (mm) } & $29.95 \pm 0.62$ & $21.59 \pm 0.36$ & $132.282^{* * *}$ \\
\hline 13. & \multicolumn{2}{|c|}{ Fruit breadth (mm) } & $9.05 \pm 0.18$ & $7.58 \pm 0.09$ & $49.248^{* * *}$ \\
\hline 14. & \multicolumn{2}{|c|}{ Fruit thickness (mm) } & $6.78 \pm 0.10$ & $5.68 \pm 0.08$ & $71.715^{* * *}$ \\
\hline 15. & \multicolumn{2}{|c|}{ Seed length (mm) } & $2.99 \pm 0.04$ & $3.05 \pm 0.02$ & $1.451 \mathrm{NS}$ \\
\hline 16. & \multicolumn{2}{|c|}{ Seed width (mm) } & $2.11 \pm 0.04$ & $1.80 \pm 0.02$ & $32.821^{* * *}$ \\
\hline 17. & \multicolumn{2}{|c|}{ Seed thickness (mm) } & $0.80 \pm 0.01$ & $0.86 \pm 0.02$ & $8.338^{* *}$ \\
\hline 18. & \multicolumn{2}{|c|}{ No. of seed per locule } & $25.40 \pm 1.22$ & $13.27 \pm 0.27$ & $92.799^{* * *}$ \\
\hline 19. & \multicolumn{2}{|c|}{ No of seed per fruit } & $101.60 \pm 4.92$ & $53.10 \pm 1.08$ & $92.799^{* * *}$ \\
\hline 20. & \multicolumn{2}{|c|}{100 seed weight } & $0.16 \pm 0.01$ & $0.35 \pm 0.06$ & $7.977^{* *}$ \\
\hline
\end{tabular}

$\mathrm{SE}=$ Standard error, * Significant at $\mathrm{P}<0.05$ level; ** significant at $\mathrm{P}<0.01$ level; ***Significant at $\mathrm{P}<0.001$ level; NS= Non significant

Table 3. Crossability of Sesamum species

\begin{tabular}{|l|l|l|l|l|l|}
\hline Sl. No. & Crosses & No. of & crosses & Compatible crosses & No. of seeds per capsule \\
\hline 1 & S. radiatum x S. indicum & & 10 & 10 & $36-39$ \\
\hline 2 & S. indicum x S. radiatum & & 10 & 0 & 0 \\
\hline
\end{tabular}

Table 4. Floral visitors of Sesamum species

\begin{tabular}{|l|l|l|l|l|l|}
\hline Sl. No. & Name of the taxa and family & Order & Visiting time & Foraging hours & Time spent in each flower (sec) \\
\hline 1 & $\begin{array}{l}\text { Xylocopa latipes } \\
\text { Apidae }\end{array}$ & Hymenoptera & Day & $09.00-11-30 \mathrm{am}$ & $6-8$ \\
\hline 2 & $\begin{array}{l}\text { Xylocopa sp. } \\
\text { Apidae. }\end{array}$ & Hymenoptera & Day & $09.30-11-00 \mathrm{am}$ & $3-5$ \\
\hline 3 & Bombus sp.1 Apidae. & Hymenoptera & Day & $11.00-02.30 \mathrm{pm}$ & $4-6$ \\
\hline 4 & $\begin{array}{l}\text { Bombus sp. } \\
\text { Apidae. }\end{array}$ & Hymenoptera & Day & $\begin{array}{l}10.00 \mathrm{am}-12.00 \mathrm{pm} \\
04.00-05.30 \mathrm{pm}\end{array}$ & $22-24$ \\
\hline 5 & $\begin{array}{l}\text { Apis dorsata } \\
\text { Apidae. }\end{array}$ & Hymenoptera & Day & $10.00 \mathrm{am}-12.00 \mathrm{pm}$ & $10-13$ \\
\hline 6 & $\begin{array}{l}\text { Amegilla sp. } \\
\text { Apidae }\end{array}$ & Hymenoptera & Day & $10.00 \mathrm{am}-12.00 \mathrm{pm}$ & $2-3$ \\
\hline 7 & $\begin{array}{l}\text { Anthidium sp. } \\
\text { Megachilidae }\end{array}$ & Hymenoptera & Day & $10.00 \mathrm{am}-12.00 \mathrm{pm}$ & $3-5$ \\
\hline 8 & $\begin{array}{l}\text { Anthophora albigena } \\
\text { Anthophoridae }\end{array}$ & Hymenoptera & Day & $10.00 \mathrm{am}-12.00 \mathrm{pm}$ & $3-5$ \\
\hline 9 & $\begin{array}{l}\text { Peucetia viridians } \\
\text { Spider) Oxyopidae }\end{array}$ & Araneae & $\begin{array}{l}\text { Day and } \\
\text { Night }\end{array}$ & & \\
\hline 10 & $\begin{array}{l}\text { Black and red Ants } \\
\text { Formicidae }\end{array}$ & Hymenoptera & $\begin{array}{l}\text { Day and } \\
\text { Night }\end{array}$ & & \\
\hline
\end{tabular}




\subsection{Seed Germination Assay}

Seeds germinated on cotton soaked with distilled water showed differences in the nature of germination. Seeds of the cultivated species germinated within two days after sowing, while in the wild species only a few seeds were germinated after 5- 6 days of sowing. Seed viability was confirmed by Tetrazolium salts, and it was noticed that slight differences in the formation of formazan, at viable seeds showed red colouration, while nonviable seeds remained unstained or white in colour. About $88-93 \%$ of the seeds were viable in both the species.

\section{Discussion}

The data obtained in the present investigation from morphology and reproductive biology was used to discuss the interrelationship and reproductive success in wild and cultivated species of Sesamum. The species showed slight variations with respect to flowering, fruiting and senescence. The senescence phase and the floral longevity were found to be same in the wild and cultivated species. Analysis of the period of flowering revealed that the duration of flowering and fruiting was comparatively short in S. indicum. This indicates that the wild species can produce comparatively a greater number of flowers, fruits and seeds, which is an advantage over the cultivated variety. Difference was observed between the wild and cultivated species in the number of nodes to first flower. In $S$. radiatum the first flower was born on the $12^{\text {th }}$ or $13^{\text {th }}$ node, but in the cultivated species it was on the $8^{\text {th }}$ or $9^{\text {th }}$ node, indicating that the cultivated species are of early flowering type compared to the wild type. The study revealed earlier blooming, anthesis, anther dehiscence, and stigma receptivity in $S$. indicum compared to $S$. radiatum.

Analysis of qualitative characters of the cultivated and wild species of Sesamum revealed that the two species differed in most of the characters except in stem shape and root system. According to Bruce et al. leaves are often varying on the same plant and often heteromorphic [5]. It was found that the quantitative characters showed variations in almost all the traits except in plant height. Height of the plant varied from 50- $150 \mathrm{~cm}$ in both. Superiority of the wild taxon in the length of capsule and in the number of seeds per capsule indicates its utility in sesame breeding programs.

Floral biology showed that the flowers were solitary, axillary, irregular, hermaphrodite (bisexual), complete, zygomorphic, slightly pedicilled and hairy and were arranged in the acropetal succession in both the species. But they differed from each other in flower colour, hairiness, pigmentation on corolla, lower lip of corolla, and number of ovules in the ovary. The extrafloral nectary glands present in the plants helped to attract the insects.
The pollen- ovule ratio was comparatively high in the wild species than the cultivated one (Table 1). According to Crudens the values between 31.9- 396.0 are facultative autogamous [9].

The data on pollen histochemistry from the current investigation indicated that the pollen grains contained high amount of protein and starch and a lesser amount of lipids. It stressed the self-pollinated nature of the crops as suggested by Baker and Baker that the pollen grains of self-pollinated plants are starchier than out crossers [3].

Assessment of pollen quality and its vigour are the prerequisites for pollination studies. High percentage of pollen fertility of the species suggests their use in the hybridization programme. Analysis of pollen viability by in-vitro and in-vivo methods suggests high percentage of pollen viability (82- 86\%) in the two species. High viability of pollen grains was confirmed by the FCR test. In- vivo technique by the cotton blue method revealed that the percentage of germination of pollen grains on the stigmatic surface was more in cultivated taxon compared to the wild taxon.

Seed germination study revealed that both the taxa showed epigeal type of seed germination. Seeds of the cultivated species germinated earlier than those of wild species. But comparatively high percentage of viability observed in the species by tetrazolium assay suggests that delayed seed germination in wild may be due to its rough seed coat, or due to the influence of environmental factors such as oxygen, water, temperature, and light.

Pollination studies performed in the species revealed that freshly opened flowers were attracted by insects. It was found that the pollinators were active during day time especially in between 09- $00-12.00$ hours and 03.00 04.00 hours. The sudden decrease in the insect visit noticed till 03.00 hours may be due to the rise in the atmospheric temperature. Average time spent by an insect on a flower was 3-5 seconds, while a few insects spent more than 20 seconds. This implied that the insect foraging speed was very fast. The receptive stigma along with stamens located in the anterior portion of the flower helped the insect to carry the pollen grains on the head portion when they entered the flower for nectar. They transferred the pollen grains to the stigma of other flowers upon landing or while searching for nectar.

The present study found out that the species of Xylocopa was the frequent visitors in S. indicum and $S$. radiatum. The nectar robbers like black and brown coloured ants were visited the species apart from the insects. This study identified that most of the pollinators are belonging to the order Hymenoptera, while a few are from other orders. Mahfouz et al. reported that the pollinators visited in the sesame belonging to order Hymenoptera, Diptera, Lepidoptera, and Coleoptera of class Insecta [16]. An interesting observation was that number of spiders especially Peucetia viridians commonly known as Green 
Lynx spider found associated with $S$. indicum and $S$. radiatum, were not true pollinators but they trapped and ate the insect pollinators while they came to pollinate the flowers (Figs. 2g, h, k).

The study observed a negligible rate of cross pollination, even if the plants were foraged by various insects. Only a few insects freely entered the flowers and successfully suck the nectar, while others were not. For this, they made a hole at the base of corolla tube to suck the nectar. It may be due to the shape of the flower, availability of space inside the corolla, size and weight of the insects foraging the plants. According to Oplinger et al., the flowers of sesame are typically self-pollinated, although they may be cross pollinated by insects [18]. This is mainly because pollinating insects prefer flowers of other species if available [18], [2].

The reproductive success of the species was analyzed by breeding experiments. Interspecific crosses carried out in the study revealed that the crosses between $S$. radiatum, (as pistillate parent) and $S$. indicum (as male parent) were successful. Though the fruit and seed set were normal, the number of seeds were less (36- 39 seeds). The seeds obtained from the cross were non-viable i.e., the seeds do not contain viable embryos (Figs.2i, m). The successful pollination and pollen germination observed in the cross suggested that the presence of non-viable seeds may be due to some abnormality in the later stages of development. But they failed to set fruit in the reciprocal cross. Similar result was reported in the interspecific cross between Arabidopsis thaliana and A. arenosa [6]. The endosperm and embryo development in the incompatible cross combination was reported by Dhawan in the cross $S$. radiatum $(2 n=64) \times S$. indicum $(2 \mathrm{n}=26)$ the embryos were viable, but the seeds were shriveled in the reciprocal cross that may be due to the post fertilization abortion of endosperm about 48 hours of pollination, leading to the starvation and collapse of the zygote [11]. Mating within the species (Autogamy) stressed that self-pollinated mode of reproduction and that self-pollination is the most efficient method in terms of fruit set both in the wild and cultivated plants of Sesamum.

The study reported the reproductive biology of the wild species $S$. radiatum for the first time and the present investigation provides the direction for the genetic improvement of the crop.

\section{Acknowledgements}

The authors are grateful to the Head, Department of Botany, University of Kerala for the facilities provided.

\section{Conflict of Interest}

The authors declare that they have no conflict of interest.

\section{REFERENCES}

[1] Ashakumary L, Rouyer I, Takahashi Y, Ide T, Fukuda N, Aoyama T, Hashimoto T, Mizugaki M \& Sugano M (1999) Sesamin, a sesame lignan, is a potent inducer of hepatic fatty acid oxidation in the rat. Metabolism 1; 48(10):1303-1313.

[2] Ashri A (2010) Sesame breeding. Plant Breeding Reviews, Volume 16. John Wiley \& Sons Inc: Oxford.

[3] Baker HG \& Baker I (1979) Starch in angiosperm pollen grains and its evolutionary significance. American Journal of Botany 66 (5): 591-600.

[4] Brewbaker JL \& Kwack BH (1963) The essential role of calcium ion in pollen germination and pollen tube growth. American Journal of Botany 50 (9):859-865.

[5] Bruce EA (1953) Notes on African pedaliaceae. Kew Bulletin 1:417-29.

[6] Burkart-Waco D, Josefsson C, Dilkes BR, Kozloff N, Torjek O, Meyer R, Altmann T, \& Comai L (2011) Hybrid incompatibility in Arabidopsis is determined by a multi-locus genetic network. Plant physiology 1: 111.

[7] Carvalho PG, Borghetti F, Buckeridge MS, Morhy L, \& Ferreira Filho EX (2001) Temperature-dependent germination and endo-beta-mannanase activity in sesame seeds. Revista Brasileira de Fisiologia Vegetal 13(2):139-48

[8] Cottrell HJ (1947) Tetrazolium salt as a seed germination indicator. Nature 159(4048):748.

[9] Cruden RW (1977) Pollen-ovule ratios: a conservative indicator of breeding systems in flowering plants. Evolution 31(1):32-46.

[10] Dansi A, Adjatin A, Adoukonou-Sagbadja H, Faladé V, Yedomonhan H, Odou D, Dossou B (2008) Traditional leafy vegetables and their use in the Benin Republic. Genetic Resources and Crop Evolution 1;55 (8):1239-56.

[11] Dhawan NL (1946) Interspecific hybridization in Sesamum. (M.Sc. (Ag.) Thesis), Indian Agricultural Research Institute, New Delhi

[12] Heslop-Harrison J \& Heslop-Harrison Y (1970) Evaluation of pollen viability by enzymatically induced fluorescence; intracellular hydrolysis of fluorescein diacetate. Stain technology 1; 45(3):115-20.

[13] Kearns CA \& Inouye DW (1993) Techniques for pollination biologists. University press of Colorado.

[14] Konan AB, Amonkan AK, Ahui ML, Bouafou GM, Kouakou LK, Kpahe FZ, \& Datte JY (2011). Myostimulating effect of Sesamum radiatum aqueous leaf extract in isolated Guinea-pig Taenia caeci contractile activity. African journal of traditional, complementary, and alternative medicines: 8(4), 377-385.

[15] Kobayashi T (1981) The wild and cultivated species in the genus Sesamum. FAO Plant Production and Protection Papers.

[16] Mahfouz H, Kamel S, Belal A \& Said M (2012) Pollinators visiting sesame (Sesamum indicum L.) seed crop with reference to foraging activity of some bee species. Cercetari 
Agronomice in Moldova 1; 45(2):49-55.

[17] Nimmakayala P, Perumal R, Mulpuri S, \& Reddy UK (2011) Sesamum. In Wild Crop Relatives: Genomic and Breeding Resources. Springer, Berlin, Heidelberg: 261-273.

[18] Oplinger ES, Putnam DH, Kaminski AR, Hanson CV, Oelke EA, Schulte EE, \& Doll JD (1990) Sesame. Alternative field crop manual. University of Winsconsin Extension/University of Minnesota: Center for alternative plant and animal products and the Minnesota Extension Service.

[19] Prabakaran AJ (1992) Identification of male sterile sources through wide hybridization and induced mutagenesis in sesame (Sesamum indicum L.) (Ph. D. Thesis, TNAU, Coimbatore)

[20] Ramanathan K (1950) A note on the interspecific hybridization in Sesamum. Madras Agricultural Journal 37:397-400.

[21] Schumann K, Engler A, Prantl K (1895) Die natürlichen pflanzenfamilien:1-56.

[22] Shivanna KR, Rangaswamy NS (1992) Pollen biology: A laboratory manual. Springer, Berlin/Heidelberg.

[23] Tandon R, Shivanna KR, \& Mohan Ram HY (2003) Reproductive biology of Butea monosperma (Fabaceae). Annals of Botany 1; 92 (5):715-23. 